This Section of Epidemiology and Psychiatric Sciences appears in each issue of the Journal and is dedicated to all forms of creative production born of an intimate and individual urge, often secretive, unbound from the conventional art system rules. Through short descriptions of the Outsider art work of prominent artists and new protagonists often hosted in community mental health services, this section intends to investigate the latest developments of the contemporary art scene, where the distances between the edge and the center are becoming more and more vague.

Carole Tansella, Section Editor

\title{
William Douglas, artist: I am dying. So are you
}

\section{R. Lentz}

Project Onward, Chicago, Illinois, USA

Received 2 August 2015; Accepted 29 September 2015; First published online 29 October 2015

Key words: Contemporary art, dreams, mental health, outsider art.

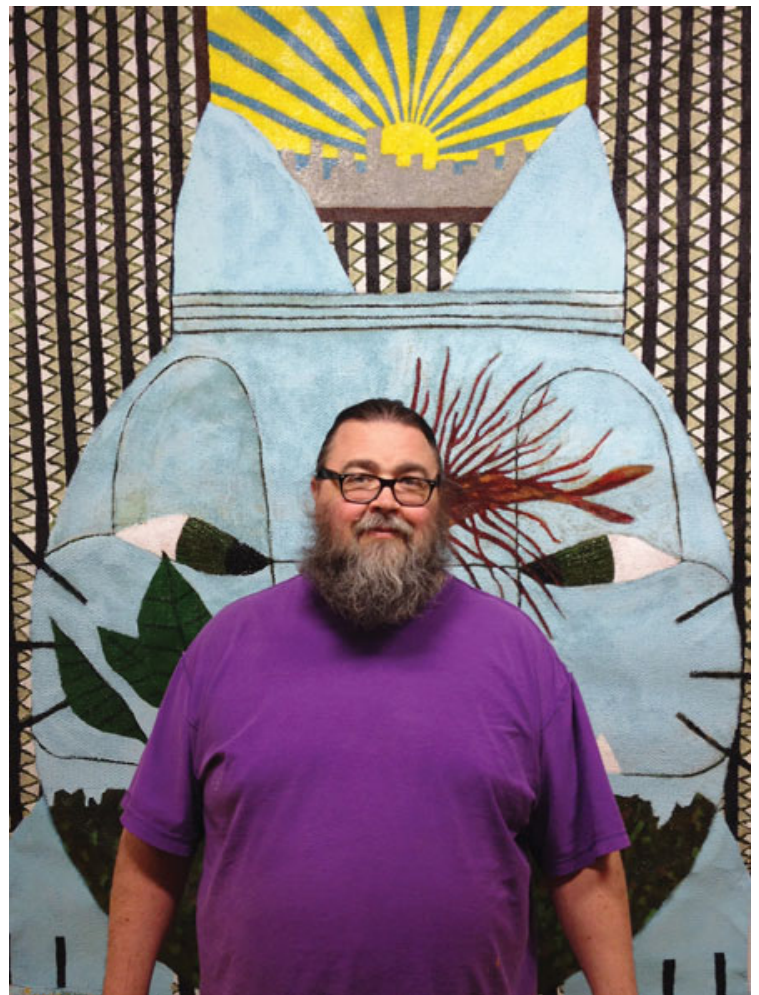

Fig. 1. William Douglas, Artist, with detail of Blue Cat, acrylic on blanket.

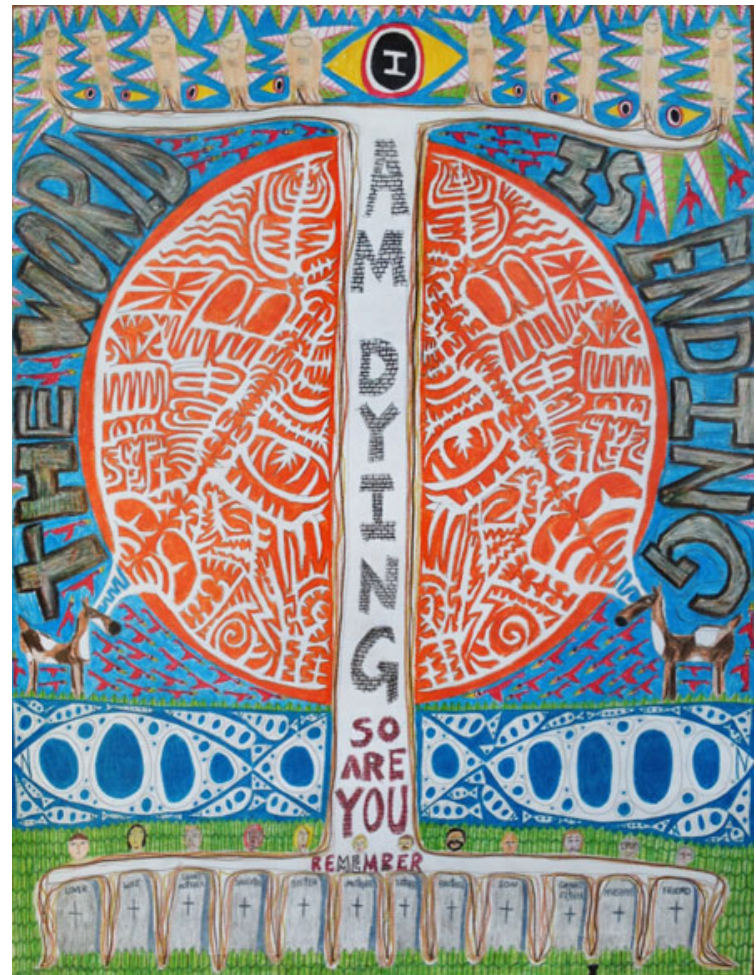

Fig. 2. William Douglas, I Am Dying. So Are You. Remember Me., colored pencil on paper, 2012.

Address for correspondence: R. Lentz, Project Onward, Chicago, Illinois 60609, USA.

(Email: rob.lentz@projectonward.org) 
The South Fork of the Chicago River creeps past the factories and warehouses of the working-class neighbourhood of Bridgeport. Artist William Douglas picks his way along the rocky riverbank, looking for inspiration among the driftwood and the rusted debris. Here the river is known affectionately as Bubbly Creek, for the slaughterhouse effluvia that roiled the murky South Side waterway during the heyday of the Union Stockyards. 'The grease and chemicals that are poured into it undergo all sorts of strange transformations,' Upton Sinclair wrote in The Jungle, 'as if huge fish were feeding in it, or great leviathans disporting themselves in its depths' (Sinclair, 1906/1980).

The stockyards are gone now, and these days, the stony shore where Douglas scavenges materials for his artwork lies in the immense shadow of the Bridgeport Art Center, a renovated brick warehouse that looms over Bubbly Creek at 35th Street. Douglas works here in the studio of Project Onward, a nonprofit organisation that provides workspace, art materials and professional opportunities to 60 visual artists with mental and developmental disabilities (http://projectonward.org). At 48, Douglas has lived with depression and anxiety for decades, but he affirms that art 'helps me get through everything' (Douglas, 2015). Douglas is a fixture of the communal studio, a kind of village elder, and he always makes time to listen and offer advice to younger artists, many of whom are living with autism or mental illness.

Douglas' imposing frame, blacksmith's beard and Southern accent favour the mountain folkways of his native east Tennessee. He recalls that the creative urge was in him from an early age; he was 'always making things in the woods' (Douglas, 2015). Even now, those rambles along Bubbly Creek reflect the artist's enduring bond with the landscape. The corrupted and recovering waterway yields up fodder for Douglas' work: both the raw materials to produce his sculptures and the potent symbolism that infuses his current drawings.

Douglas infuses his art with dark humour and sly references, but it is not ironic. Sadness and anxiety nibble at the edges of his work, or else swallow it whole. In 2012, the death of Douglas' mother was followed 6 months later by his father's suicide. The trauma of losing both parents was devastating, and he sank into a crippling depression, unable to work. In a coincidental nod to Bubbly Creek, the author William Styron describes his own depression as 'a sense that my thought process was being engulfed by a toxic and unnameable tide that obliterated any enjoyable response to the living world' (Styron, 1992). But at a decisive moment, Douglas recalls, he chose to 'try to turn my avatar around and get done as much as possible. ' He had always been a compulsive maker, but everything had changed now, and he vowed to himself that art making would be his primary goal - no matter what.

The ordeal had another effect on the artist: 'I knew death, like I'd never known it before,' he says. 'Now I talk to Death' (Douglas, 2015). With unsettling clarity, Douglas describes what he terms prophetic dreams. In these dreams, he sees into the future, including images of his own death. Dreams hold a particular power for the artist, who has been recording the contents of his dreams since he was 18. 'Dreams are like time travel,' he says, and he always remembers them (Douglas, 2015). The details and images of his dreams are noted on scraps of paper, which are pasted into the pages of spiral notebooks or scrapbooks, numbering in the dozens and bursting at the seams.

In a fascinating series of drawings, the artist depicts his own burial, drawn from the bottom of the grave looking up at swaying trees and a terrifying sky, or portraying the artist's own headstone ('William Douglas, Artist'), with a date of death that varies widely from drawing to drawing.

But is this outsider art? In Artistry of the Mentally Ill, psychiatrist Hans Prinzhorn wrote of the 'expressive urge' as 'a dark, involuntary compulsion' (Prinzhorn, 1922/1972). Jean Dubuffet similarly described art brut as 'flourishings of an exalted feverishness' born of 'pure and authentic creative impulses' (Dubuffet, 1967/1988). On the surface, Douglas' output, along with his history of mental illness, suggests the work of a true outsider artist: the sheer volume of his work, the rambling variety and eccentricity of its production, and its often prophetic qualities.

But Douglas will have none of it. Of his relation to artistic fashion, the artist would only shrug and say, 'I would like to leave something behind' (Douglas, 2015). Douglas' legacy may well be the tangled, deathhaunted geography that so often finds its way into his drawings, but within the prophetic darkness of that landscape lies the hope of recovery and wisdom. And a river creeps through it.

\section{Acknowledgements}

None.

\section{Financial Support}

None.

\section{Conflict of Interest}

None. 


\section{References}

Douglas W (2015). Interviewed by: Lentz R (30 June 2015).

Dubuffet J (1988). Make Way for Incivism, trans. C Khan Malek and A Weiss. Art \& Text, no. 27, December 1987-February 1988. (Original work published 1967).

Prinzhorn H (1972). Artistry of the Mentally Ill: A Contribution to the Psychology and Psychopathology of Configuration, translator von Brockdorff E. Springer-Verlag: Wien, NY (Original work published 1922).

Sinclair U (1980). The Jungle. New American Library: New York, NY (Original work published 1906).

Styron W (1992). Darkness Visible: A Memoir of Madness. Vintage: New York, NY.

\section{About the author}

Rob Lentz is co-founder and Executive Director of Project Onward. He received his Master of Fine Art degree from The School of the Art Institute of Chicago in 1997. While serving as Director of Visual
Art for Gallery 37, the City of Chicago's job training programme in the arts for high school students, Lentz identified an urgent need for meaningful creative outlets for artists with disabilities who were transitioning into adulthood and leaving behind the social services available in the public school system. Project Onward began in 2004 in a small classroom with eight artists on the autism spectrum or with severe learning disabilities. Today, over 55 artists with mental and developmental disabilities (aged 2075) have access to an expansive studio and an on-site gallery in Project Onward's facility at the Bridgeport Art Center. Their artwork is in a number of public and private collections, and has been exhibited around the world. Lentz is an artist, curator, writer and advocate for disability arts. His own installations, sculptures and drawings have been exhibited nationally.

Carole Tansella, Section Editor 